\title{
Draft Minutes
}

APSA Council Meeting

\section{American Political Science Association Annual Meeting September 1, 1999 \\ Atlanta Hilton Atlanta, Georgia}

Present:

Council Members: Matthew Holden, Jr., Robert Keohane, Jane Bayes, Tim Cook, Gary Cox, Jean Bethke Elshtain, Ada Finifter, Luis Fraga, Charles Hadley, Germaine Hoston, Cynthia McClintock, Eileen McDonagh, Nancy McGlen, Kristen Monroe, Pippa A. Norris, Catherine Rudder, Alberta Sbragia, Kay Schlozman, Howard Silver, Beth Simmons, Paul Sniderman, James Stimson, J. Ann Tickner, Joan Tronto, Michael Wallerstein

Council Nominees: Randall Calvert, William Galston, Robert Jervis, Edmond Keller, Gary King, Atul Kohi, George Marcus, Guillermo O'Donnell, David Rayside, Christine Sierra, Roberta Sigel, Sven Steinmo

Guest: Charles Johnson

APSA Staff: Jeffrey Biggs, Sue Davis, Robeit J.P. Hauck, Sheilah Mann, Rovilla McHenry, Maurice Woodard

\section{President Holden welcomed the members of the Council to the Atlanta meeting.}

Following introductions of Council members and guests, the Council minutes of April 17, 1999 were approved with the following modifications:

A. Tim Cook corrected the minutes to reflect that the Council had unanimously voted to send a letter to be signed by the president or executive director to the president of the University of Pittsburgh with respect to that institution's policy regarding domestic partners. (He took the opportunity to circulate a letter that he had drafted for the Council's response.)

B. The Council agreed that APSR Editor Ada Finifter's elaboration be attached to the minutes and suggested that in the future Council members may elaborate on their statements. The proposal for written rather than oral reports to the Council should make such occasions less frequent in the future.

\section{Report of the President}

A. President Holden indicated he would leave written notes reviewing his past presidential year, and would elect to handle the action items of the previ- ous day's Administrative Committee as they came up on the Council agenda.

B. The Council agreed to an extension of the Ad Hoc Committee on Political Science and the National Science Foundation (NSF) to April 2000. President Holden indicated that, at his request, he had replaced Michael Dawson of the University of Chicago with Christopher Davenport of the University of Colorado. The Council then approved this action. At the president's request, Paul Sniderman noted the excellent NSF support to the discipline in the past.

C. Matthew Holden urged members of the Council to attend the Annual Meeting's special events and underscored his considerable respect for the 1999 Annual Meeting co-chairs Alberta Sbragia and John Garcia.

\section{Report of the Executive Director}

A. Catherine Rudder expressed her appreciation for the work of President Matthew Holden, Council members, and 1999 Program Chairs Alberta Sbragia and John Garcia over the course of the year.

B. The Council approved the previous day's Administrative Committee recommendation of a joint membership arrangement with the American Association of Political Consultants. Holden added his personal suggestion that in the future APSA consider a similar relationship with the American Bar Association.

C. The executive director introduced new APSA staff member Sue Davis, formerly on the faculty of Grand Valley State University in Grand Rapids, Michigan, who will be responsible for international programs, Organized Sections, State Associations, Departmental Services surveys, Small Research Grants, and Status Committees on Women, and Gays and Lesbians in the Profession.

D. The Council approved the 1999 annual business meeting agenda.

\section{Officer and Council Nominations Approved}

The Council unanimously approved the Standing and Award Committee appointments of President-Elect Robert Keohane of Duke University, who indicated his pride at the quality of the prospective committee members.

\section{Report of the APSA Treasurer}

A. Timothy Cook indicated that the Association's financial status was even better than in his April forecast and that 1999 should end on a positive note. At the heart of the new Strategic Planning Process on the revenue side of the ledger, Cook stated, should be the Association's declining membership which is concentrated among the profession's lowest dues-paying members (e.g. students and the entering academic levels of temporary and assistant professors). This decline, along with the decline in institutional membership, has greater import for the Association than the impact on overall revenues alone. Advertising revenues, particularly in $P S$, have increased as has the income from permissions for reprinting.

On the expense side, Cook indicated that the tight fiscal policies pursued by APSA staff have resulted in the Association's running a surplus. Thus, there is no need to draw down on the Trust and Development Fund, an action the Council is authorized to do up to $4.5 \%$ of the principal. Council approval of the previous day's Administrative Committee recommendation to authorize a $\$ 5,000 \mathrm{in}$ crease in the Strategic Planning Process budget would result in an essentially balanced budget.

During the discussion following the treasurer's motion for final approval of the budget, President-Elect Keohane emphasized that with expenses rising at $4 \%$ and revenues by $3 \%$, while there is no immediate cause for alarm, the longrun trends are clearly negative. If the APSA staff had not held down expenses and the Association had been on budget this year, APSA would have had to draw down on the Trust and Development Fund as will be necessary next ycar. It will not be sustainable for expenses to continue to rise at a higher rate than revenues. Paul Sniderman endorsed the record of good management. Ada Finifter queried whether there was a method of determining how the membership decline could be measured against the available political science pool of professionals. Kay Schlozman emphasized that the declining membership trend as a reality which must be confronted.

At the conclusion of discussion, the Council approved the revised 1999-2000 budget.

B. Rob Hauck provided background on the Administrative Committee's rec- 
ommendation to the Council on pending litigation concerning APSA's non-profit tax exemption status in the District of Columbia. Recognizing that there is no cerlainty in the outcome, the Committee recommended that the Council authorize up to $\$ 60,000$ to pursue its real estate tax appeal with the D.C. Superior Court. A courl ruling in favor of APSA could result in the return of as much as $\$ 500,000$ in back taxes and an annual exemption of $\$ 70.000$ in taxes in the future. The Council approved the $\$ 60,000$ draw down from the Trust and Development Fund to cover the estimated legal fees, if the Administrative Committee decides that proceeding would be prudent.

\section{Council Consideration of a Draft Design for Strategic Planning}

Led by President Holden, PresidentElect Keohane, and Executive Director Rudder, the Council discussed strategic pkanning at length. Bob Keohane stressed that the members of the Strategic Planning Committee must be individuals who can reach out to constituencies and provide the basis for a strong consensus within APSA. As outlined in her draft design submitted at the Council's request, Cathy Rudder emphasized the importance of the committee's focusing on key priorities and making recommendations about crucial choices to be made. As submitted to the Council, the Administrative Committee's consideration highlighted the importance of how to respond to increasing financial stringency and decreasing membership in APSA, particularly of younger scholars. The Administrative Committee forwarded to the Council two changes in the executive director's memo: 1) The committee should be a commission on setting the priorities of the Association and not on constitutional revision, and 2) The committee's charge should include "the prevalent, most pressing issues, or critical choices that must be made, including those pertaining to membership. revenues, services, and publications."

Keohane conceded it would have to be al tough-minded process because the committee would be dealing with a number of forces over which the Association has no control. Referring to the April Council meeting discussion in Chicago on the menubership surveys, Keohane felt the committee should be authorized to conduct comparable surveys if needed. Jane Bayes expressed the hope the Committec would seek input from the regional associations, a view endorsed by Matthew Holden, who stated that, out ol regard for various concerns about status, he has taken to referring to "cognate" bodies. Nancy McGlen suggested that the process also needed to be attentive to the views of "gypsy" academics who lack career long-term stability and those in smaller schools whose membership in APSA is low. Michael Wallerstein suggested that the committee's agenda include a long-term look at the increasing complexity of the Annual Mectings.

Bob Keohane reemphasized his concern that members of the Strategic Planning Committee possess not only analytical ability but the capacity to engage in far-ranging contacts with various political science constituencies. He indicated he would also like some overlap with Council and budget experience and that, to cover all the bases, he felt as many as nine (9) committee members would be required. The Council approved the proposal with a reporting deadline for the committee of August 2000.

\section{1999 Annual Meeting Report}

Co-chair Alberta Sbragia reported for herself and co-chair John Garcia whose plane had been delayed. She confessed that the past year had been a true administrative experience, that is, difficult. She noted that most faculty members had little experience of working with staff, and that there were many more APSA constituencies to work with than she had ever imagined. She was generous in her praise of APSA staff whom she characterized as having done a firstrate job. (Note: Although the figures were unavailable at the time, the Atlanta mecting, while attracting $13 \%$ fewer participants than the record-breaking 1998 meeting, was the largest APSA annual Meeting held in the South.)

\section{2000 Annual Meeting Report}

President-Elect Robert Keohane announced his choice of Ira Katznclson and Helen Milner as co-chairs for the 2000 APSA Annual Meeting in Washington, DC, and cautioned everyone to be attentive to the electronic submissions deadlines.

\section{Annual Meeting Fee Changes}

The Council endorsed the recommendation of the Annual Mecting and Administrative Committees that the 2000 base Annual Mecting preregistration fee be increased by $\$ 15$ for members and $\$ 5$ for students and, beginning with the 2001 Annual Meeting, institute an annual $5 \%$ increase in lieu of a larger triennial increase. The proposal established a new baseline that can be adjusted by future Councils.

\section{Report of the Ad Hoc Committee on Technology}

Pippa Norris alerted the Council to the relaunch of the APSA web site with its attractive redesign and navigation bar. She singled out APSA staff member and webmaster Scan Twombly for his unstinting work on the project. She outlined new electronic APSA services including the electronic job placement process, which was introduced at the Atlanta meeting and the electronic submission process for the fortheoming APSA Membership Directory.

She admitted that several unresolved issues foreed her to temper her enthusiasm. Among these issues are that advertising on the web has thus far not provided much revenue and that there will be demand for services not currently being provided. She concluded by asking how we can facilitate more cross-communication within APSA.

\section{Report on the APSA Centennial Campaign}

Rob Hauck's enthusiastic oral report on the Campaign focused on the impressive progress of new initiatives including the Jewel Prestage-Richard Fenno endowment in support of the Ralph Bunche Summer Institute, an effort being launched at the Atlanta meeting; the Ostrom/Awan Endowment for civic education; and the Walter Beach endowment to provide political science student travel grants.

Cathy Rudder expressed appreciation to Centennial Campaign Co-Chairs Dale Rogers Marshall and Jack W. Peltason, Rob Hauck, and the generosity of APSA members, all of whom represented a belief of political scientists in their causepaving the road for the coming generations in the discipline.

\section{Report of the APSR Editor}

Ada Finifter provided Council members with preliminary tables that would be included in her annual report. The level of annual submissions has remained constant, but represented an increase over previous editorships with a final acceptance rate across ficlds of around $9 \%$. She noted that American Politics submissions have risen again. Although only $2 \%$ of submissions were accepted on the first reading, some $60 \%$ of articles are accepted after the first revisions. Operating expenses for 1999 amounted to $\$ 133,000$, not including 
Michigan State's contribution to the Review or printing and mailing expenses.

Pressure continued unabaled to accommodate book review requests, which average $80-90$ per issue. The section is currently supervised by one editor and two interns. The Review plans to accept any $A P S R$ author's offer of additional information for the APSR web site, which would also include a list of all books received, whether reviewed or not.

The editor indicated that she was in the last two years of her editorship and, following past procedures, a new editor would require one year's lead time with appointment by August 2000). Reflecting on those areas which would require particular attention, perhaps by the Strategic Planning Committec, Ada Finifter focused on: 1) The size of the APSA publication program, which she felt is small relative to those of other academic associations. Perhaps there is a need for more journals to accommodate the diversity within political science or a single journal devoted to book reviews alone as is the ease of the Joumal of Economic Literature. 2) Although added expenses would be required, she felt the structure of the editorship needs to be looked at with the possibility of several editors. 3) more attention should be paid to electronic publication beyond JSTOR, which serves primarily an archival purpose. The political science constituents may prefer to have electronic access to current issues of journals, which has its own economic implications.

In response to queries from Council members during the discussion, the editor noted the difficulty of finding sufficient book reviewers since there is not much academic "credit" given to their efforts. To enhance the rewards that do exist, she moved book reviewers to the main table of contents and carried the revicwers' names at the top rather than the bottom of the review. Another explanation for the difficulties in recruiting book revicwers might be the increased preference for rescarch as suggested by the greater case of getling article reviewers. President Matthew Holden thanked Ada Finifter for her comprehensive report.

\section{Creation of New Organized Section on Interdisciplinary Approaches to History and Politics}

The Council approved the Administrative Committee's recommendation for the creation of a new Organized Section on Interdisciplinary Approaches to History and Politics. During the brief discussion, a cautionary note was offered concerning the discipline's need to avert future dangers of intellectual and organizational fragmentation.

\section{Report of the Committee on Education and Professional Development}

In his sobering preliminary oral report, Charles Johnson indicated that last year roughly one-third of applicants on the market, or 400 out of 1,100 candidates, received tenure track positions. Another third got non tenure track positions, and the final third accepted other positions or remained at their graduate school institutions.

Analysis of a 1996 survey of Ph.D.s on the market suggests that roughly $40 \%$ considered themselves under-employed, and some $50 \%$ were not in full-time positions.

The committee's recommendations to departments will include suggestions for professional development for both Ph.D. students and new faculty. The committee welcomes comments from the Council.

\section{Ralph Bunche Summer Institute}

Charles Hadley asked for clarification of cligible applicants for the Ralph Bunche Summer Institute program. Cathy Rudder apologized for any confusion and indicated that the program now includes Latinos, Native Americans, and African Americans.

\section{New Business}

Having generally followed the procedure for the current meeting, the Council formally endorsed the Administrative Committee proposal that future Council agendas be divided into action items and written reports. Anyone delivering a report to the Council will be asked to submit written remarks. The Council will then be invited to discuss the report and ask questions as appropriate. The call for "new business" would encompass those non-action items or other topics not covered by the agenda.

Kay Schlozman requested an update on the congressionally-mandated and Office of Management and Budget (OMB) proposed implementing regulations to make U.S. Government-sponsored research available to the public. Rob Hauck noted that the deadline for final OMB regulations was September 10. He added that efforts thus far had led to improvements to the first dralt, and that a number of issues could well be ultimately resolved in the courts. Names and addresses of survey respondents, for example, would not be made public under the current draft regulations. President-Elect Robert Jervis added that the regulations would not apply to most projects typically funded by the NSF.

On improvements to the current draft regulations, APSA Executive Director Cathy Rudder extended particular thanks to COSSA Director Howard Silver, Rob Hauck, and Representative David Price of North Carolina.

\section{President Keohane Recognizes Holden}

In appreciation for his leadership over the past year, on behalf of the Council, President-Elect Robert Keohane presented President Matthew Holden with a print of Eighteenth century British cartoonist Hogarth's "The Politician" and a Certificate of Apprcciation for his service as the Association's president. Holden expressed his gratitude and the meeting was adjourned. 


\section{APSA Awards Presented at the 1999 Annual Meeting}

\section{DISSERTATION AWARDS}

\section{Gabriel A. Almond Award (\$500)}

For the best doctoral dissertation completed and accepted in 1998 or 1999 in the field of comparative politics.

Award Committee: Karen Beckwith, College of Wooster, chair; William Quandt, University of Virginia; and James Scott, Yale University.

Recipient: Daniel Nolan Posner, University of California, Los Angeles

Dissertation: "The Institutional Origins of Ethnic Politics in Zambia"

Citation: This year's Almond Dissertation Committee considered 25 outstanding dissertations in comparative politics submitted by a wide range of graduate departments, among which there were so many excellent manuscripts that, in any given year, they might have won the prize for best dissertation in comparative politics. From among these, the committee awards the American Political Science Association's 1999 Gabriel Almond Award for the Best Dissertation in Comparative Politics to Daniel Nolan Posner of Harvard University for his thesis, "The Institutional Origins of Ethnic Politics in Zambia," supervised by Samuel Huntington, Robert Bates, and Jennifer Widner. The thesis poses two central questions: First, "Why [do] political actors select one dimension of social identity rather than another for building or securing membership in advantageously sized political coalitions?" (8); second, how do formal institutional rules shape identity-based coalition formation that results in social clcavage outcomes? (10). To answer these questions, $\mathrm{Mr}$. Posner employs a comparative case study of Zambia in two time periods to cxplain coalitional differences (and coalition-building differences) under conditions of one-party and of multiparty electoral competition. In constructing his model, Mr. Posner critically conjoins the comparative political literatures on social cleavages and party systems, ethnicity and ethnic conflict, rational choice, and institutional analysis. He concludes that "tribal identities have served as the basis of electoral coalition building and voting during one-party elections and language group identities have played this role during multi-party elections" (292).

Zambia presents a useful case for testing the rational choice institutionalist model that Mr. Posner develops because Zambia has experienced two multiparty democratic systems (1964-72 and 1991 to the present) interrupted by a 20 -year period of one-party rule (1972-91). Zambia's political history permits com- parisons of identity-based coalition formations under one-party and multiparty conditions, but also comparisons of coalition construction during two periods of multipartism where key economic and developmental conditions vary significantly.

The choice of case is exccllent--wellsuited to the research questions posed and consistent with the requirements of the best comparative political research. Fully comparative across time and across state formation, the case analysis is fully theoretically undergirded. Working across multiple levels of analysis, $\mathrm{Mr}$. Posner develops a rational choice institutionalist model that is infused with a subtle and sophisticated explication of "ethnicity" as being socially constructed and rationally chosen by political actors strategically organizing their politics to fit the institutional and electoral context. As committee member William Quandt observed, the dissertation is "an exceptionally valuable contribution to the field of comparative politics [and] a model of comparative political analysis."

Mr. Posner has made excellent use of a wide range of data, so various and pertinent as to shame scholars of politics in nations where data are more readily available and more easily accessible. These include historical government documents, mining industry documents, "newspaper accounts, interviews with politicians and voters, transcripts of focus group discussions and secondary sources materials . . ; 1990 Zambian census results, election results from seven different parliamentary elections, and original data that [he] collected on the tribal backgrounds of the more than 1,000 parliamentary candidates that stood for election between 1968 and 1996 . . as well interviews, focus groups, and evidence from a large-scale attitudinal survey $(\mathrm{N}=252)$ of Zambian voters in six case study districts" (25). The multiplicity of data sources and types, and the skill with which Mr. Posner employs them to understand choices about collective identity in electoral coalition building, provide a strong foundation for the conclusions and for generalization from them to other cases.

Mr. Posner's thesis adds to the literature on party systems, collective identity, coalition formation in electoral context, and political institutional development. It contributes specifically to comparative political scholarship on Zambia, about which there is still little research, but also informs the wider political development and developing nations literature. A single country study but not a single case study, "The Institutional Origins of
Ethnic Politics in Zambia" is exemplary comparative political scholarship.

As committee member James Scott concluded, "The thesis is a rare blend of careful and original ficldwork joined to a concern with both the enduring structures of social experiences [and with] the institutional incentives provided by constructed institutions. The result is a convincing account of ethnic and linguistic political mobilization that promises to travel well to other research settings." In this summary assessment, we concur and offer our congratulations to Mr. Posner for his achievement in winning the 1999 Almond prize for best dissertation in comparative politics.

\section{William Anderson Award (\$500)}

For the best doctoral dissertation completed and accepted in 1998 or 1999 in the field of state and local government, federalism, or intergovernmental relations.

Award Committee: Deil Wright, University of North Carolina, chair; Sarah Liebschutz, State University of New York, Brockport; and James Sheffield, Wichita State University.

Recipient: Greg M. Shaw, Illinois Wesleyan University

Dissertation: "Public Opinion and Welfare Policies in the Amcrican States"

Dissertation Chair: Robert Shapiro, Columbia University

Recipient: David Buchholz, Self-Hclp Ventures Fund

Dissertation: "Competition and Corporate Incentives: Dilemmas in Economic Development"

Dissertation Chair: Peter Lange, Duke University

Citation: This data-rich and analytically complex thesis addresses the policy responsiveness of state-level policymakers to public opinion on multiple welfare policy issues from the 1980 s to the mid1990s. The research question is: Did state-level public opinion drive welfare policy change(s) made by elite decisionmakers in the states? Or did elites lcad and public opinion follow the shaping of policy choices made by the states on AFDC and Medicaid programs? The pursuit of these (and more refined) questions is sophisticated and nuanced, despite numerous challenges involving data collection and interpretation. The former include inconsistent general and specific welfare policy survey items as well as incomplete data for the 50 states. The latter involve connecting opinion changes to welfare policy changes. The author systematically and creatively surmounts these substantive and analytic challenges. Among his conclusions is one 
consistent with what V.O. Key posited several decades ago: that public opinion serves as a "boundary rather than a driver" of policy choices by elites. The thesis is an outstanding contribution to research on state politics and policy, democratic accountability, and state-national relationships. The focus on welfare makes it especially timely as political, institutional, and intergovernmental issues rise to prominence in the American federal system. In every respect, it is eminently deserving of the Anderson Award.

Citation: This thoughtful and sophisticated thesis applies a Prisoner's Dilemma game-theoretic model to the problem of interstate (interjurisdictional) competition for corporate (mega-investment) choices on plant/facility location decisions. It explores, both formally through modeling and illustratively through three in-depth case studies, the asymmetric dynamics of public-private sector bargaining in the use of incentives to influence capital investment/disinvestment choices. In addition to formal and economic analysis, the author examines political factors affecting the decision dynamics. He explains and assesses how, in addition to the asymmetry of numbers (one firm vs. many governments) and information (proprictary vs. public), the bargaining environment is dominated by uncertainty and temporal, situational, and structural factors that lead public entities to overbid in offering incentives. The roles of both elected politicians and economic development specialists are exposed to full view in the three case studies. The author draws persuasive conclusions that "incentives are massive, wasteful, negative-sum games," and that "principally noneconomic factors make up the decision about how much to bid for a firm." Among his recommendations is a call for national policies to alter the context and institutions surrounding the dilemmas of economic incentives. This thesis is a fine contribution to research on intergovernmental relationships, state politics, and political economy. It admirably merits recognition with the Anderson Award.

\section{Edward Corwin Award (\$500)}

For the best doctoral dissertation completed and accepted in 1998 or 1999 in the field of public law.

Award Committee: Susan Mezey, Loyola University of Chicago, chair; Larry Baum, Ohio State University; and Alison Renteln, University of Southern California.

Recipient: Kathleen Uradnik, St. Cloud State University

Dissertation: "Government by Consent Decree: San Francisco's Struggle for Institutional Reform"

Dissertation Chair: Robert A. Kagan, University of California, Berkeley
Citation: After careful consideration, the committee selected Dr. Kathleen Uradnik's dissertation, "Government by Consent Decree: San Francisco's Struggle for Institutional Reform" as the best doctoral dissertation in the field of public law. Uradnik's dissertation provides an intcresting analysis of an important topic. She assesses the implementation and impact of four federal consent decrees that were aimed at reforming public institutions in San Francisco: the school system, the jail, the police department, and the fire department. In three of the cases, the decrees grew out of claims of racial discrimination; the decree in the jail case involved complaints of substandard conditions.

Uradnik's analysis is situated in the context of the debate over the use of courts to achieve significant social reform and, more specifically, the litigants' ability to use a consent decree as a mechanism for systemic reform. She concludes that the litigants in the four San Francisco cases were able to achieve technical compliance with the terms of their decrees but that they largely failed to resolve the underlying issues that had prompted the litigation. Moreover, she found that the decrees had unintended consequences that created new problems for the target institutions. Based on her findings, she argues that consent decrees can succeed only under favorable circumstances, depending primarily on how they are crafted. The dissertation effectively uses a set of case studies to address an important set of theoretical issues and practical problems in the legal system. Especially impressive is the depth of Uradnik's inquiry into each case to examine why it took a particular course. She makes extensive use of court files, interviews, and secondary sources to ascertain the impact of the decrees and to probe the forces that shaped their impact. The result is a well documented set of studies that provide a strong evidentiary basis for her conclusions and allow readers to formulate their own judgments. In carrying out and interpreting her case studies, Uradnik makes a significant contribution to our understanding of the implementation of court decrees and the usefulness of litigation as an instrument of social reform.

Overall, the committee's decision was based on the subject matter of the dissertation, the massive data collection, the careful interpretation of the findings, and the clarity of the argument. Her study, which reflects an excellent use of empirical data in qualitative analysis, will be of grcat interest to scholars of law and courts as well as those who study urban politics, state and local politics, and public policy.

The committee also felt that honorable mention should go to Beth Kiyoko
Jamieson for her dissertation, "Toward a Feminist Theory of Liberty." Jamieson is concerned about the dichotomization of liberty and equality in political theory. She attempts to move beyond the debate about the meaning of equality by arguing for the importance of liberty, not as a counterpoint to equality, but in support of a more sophisticated understanding of both equality and liberty.

Her dissertation develops a conception of liberty that includes three components: identity, privacy, and agency. It assesses the implications of these components through close analysis of legal issues and legal situations in which they are relevant. Her general conception and her case studies are careful and nuanced. Through them, she effectively argues for new perspectives on liberty in the context of feminist theory and the legal system.

\section{Harold D. Lasswell Award (\$500)}

For the best doctoral dissertation completed and accepted in 1997 or 1998 in the field of policy studies.

Award Committee: Paula D. McClain. University of Virginia, chair; Ellen Mickiewicz, Duke University; and Uday Desai, Southern Illinois University.

Recipient: Adria Gallup-Black, New York University

Dissertation: "Federalism, Policy Innovation, and Welfare Reform in the American States"

Dissertation Chair: Robert Y. Shapiro, Columbia University

Citation: It is with pleasure that the committee presents the Harold D. Lalsswell Award to Adria Gallup-Black in recognition of her excellent dissertation, which stood out as exceptional among a very strong ficld of contenders.

One of the premises upon which the argument for devolution of more responsibility to states for policy solutions has been that if given the responsibility for solving problems, states will innovate solutions that will produce more positive outcomes than policies developed by the federal government. State governments are closer to the people, and are the most appropriate levels of government to devise solution for most policy problems. Moreover, states should be free from federal controls in fashioning their solutions. Clearly, this premise was present in the debate surrounding welfare reform, and the formulation of current welfare policy. Through an examination of welfare experimentation in the American states, Gallup-Black asks two questions: Does devolution spur innovation? and Does devolution through innovation produce better outcomes than what would have taken place under federal constraints? 
Utilizing the factors identified in the state politics and innovation literature that contribute to innovation in state policy making, Gallup-Black tests whether the assumptions undergirding the 1981 Omnibus Budget Reconciliation Act (OBRA) that began welfare experimentation actually led to innovation in welfare reform. Blending historical, state, federal, and interview data, Gallup-Black provides sophisticated statistical analysis of the models of innovation in state policy making. What she finds is that in the case of welfare reform, devolution did not prompt state experimentation and innovation, and the welfare policies developed by the states did not produce better outcomes. Gallup-Black has written a superb empirical study of welfare reform that adds immenscly to our understanding of not only national policy making, but state policy making and innovation as well.

While a runner-up category does not exist, the Committee wishes to acknowledge the very fine dissertations of Steven G. Anderson of the University of Michigan and Anya Elisabeth Bernstein of Harvard University.

\section{Helen Dwight Reid Award (\$500)}

For the best doctoral dissertation completed and accepted in 1998 or 1999 in the ficld of international relations, law, and politics.

Award Committec: J. Ann Tickner, University of Southern California, chair; Yang Zhong, University of Tennessee, and James Steele, North Carolina A\&T University.

Recipient: Janice Bially, Dartmouth College

Dissertation: "The Power Politics of Identity"

Citation: The 1999 Helen Dwight Reid Award goes to Janice Bially for her dissertation, "The Power Politics of Identity." Challenging the constructivist view that security communities are maintained through shared identities, Dr. Bially claims that security communities actually operate through power politics. Thus, a security community is less differcnt from an anarchical international system than is generally assumed. Dr. Bially employs a post-structuralist conception of power manifested through discourse as well as behavior; the narrative power that holds security communities together is not physically harmful, but it may be coercive, as realists have emphasized. Employing a methodology of discourse analysis, Dr. Bially examines the Special Relationship between the United States and Britain in the wake of the Sucz Crisis of 1956. Bially demonstrates how, at a time of crisis, the strains in this relationship were re- paired through narrative force, or what she calls "the power politics of identity."

What particularly impressed the committee, all of whose members enthusiastically endorse this award, was the originality and boldness of Dr. Bially's work. Her attempt to bridge constructivist and traditional views through her use of post-structuralist discourse analysis and her initiation of a conversation between realism and constructivism are innovative and intriguing. Unlike many critical scholars, Dr. Bially believes that realism still has much to tell us but that poststructuralism, with its fresh insights into the power of ideas, can complement rather than compete with realist views of the materiality of power. In policy terms, Bially brings new insights into understanding why security communities might break down and how they can be repaired before they degenerate into a situation where physical force is often employed. We congratulate Dr. Bially for an excellent dissertation that shows great depth of insight and creativity. It should appeal to conventional and critical scholars alike.

\section{E.E. Schattschneider Award (\$500)}

For the best doctoral dissertation completed or accepted in 1997 or 1998 in the field of American government and politics.

Award Committee: M. Margaret Conway, University of Florida, chair; Janet Martin, Bowdoin College; and Bruce Oppenheimer, Vanderbilt University. Recipient: Steven Paul Nicholson,

Santa Clara University

Dissertation: "Rethinking Voting Behavior: Agenda, Priming, and Spillover Effects in U.S. Elections"

Dissertation Chair: Robert Jackman, University of California, Davis

Citation: This dissertation examines a fundamental problem in how elections are interpreted. Nicholson's thesis is that agendas tic together voting decisions for different types of offices by infusing elections with shared political meanings. Agendas, therefore, creatc shared criteria for evaluating candidates in contests for different offices in one state. Changes in the content of agendas alter the critcria that voters use to evaluate candidates. Because agendas may vary from state to state, the issues that affect election outcomes would be expected to vary from state to state as well as over time.

Nicholson tests this thesis using the analytical tools of agenda setting and priming. The agenda-setting effect is examined through assessment of the issues voters specify as important in an electoral contest. Assessing how the issues deemed important affect voters' choices among candidates tests the effects of priming. Using a variety of data sources, including American National Election Study data and ABC/Washington Post exit polls, Nicholson demonstrates that voters in states with environmental, tax, abortion, and nuclear frecze issues on the agenda used those issues to evaluate candidates for different offices. States where such issues were not on the agenda did not use such issues. A further test of his thesis uses data from California clections in 1994 and 1996.

This disscrtation presents a challenge to the socio-psychological basis of electoral behavior as traditionally studied for offices other than the presidency. Nicholson focuses our attention on the varying saliency of components of electoral choice in different electoral contexts. He presents a strong case for studying elections vertically within a constituency (a state) rather than horizontally (Scnate elections, House elections, ete). His research has important implications for scholars in several areas, opening new avenues for research.

\section{Leo Strauss Award (\$500)}

For the best dissertation completed and accepted during 1997 or 1998 in the field of political philosophy.

Award Committee: Murray Dry,

Middlebury College, chair; Stephen

Macedo, Syracuse University; and Meta

Mendel-Reyes, Swarthmore College.

Recipient: Christopher Rickey, Duke University

Dissertation: "The Politics of Revelation: The Philosophical Bases of Heidegger's Religious Politics"

Dissertation Chair: Michael Gillespie, Duke University

Citation: The 1999 Leo Strauss Award Committec is pleased to announce that Christopher Rickey is the recipient of the prize for the best dissertation completed or accepted during 1997 or 1998 in the field of political philosophy.

Each member of the Committee was impressed with the importance of the author's subject, his command of the extensive material, and the comprehensiveness of his coverage.

The subject is Heidegger's philosophy and its relationship to his politics. Rickey argues that Heidegger's philosophy and his politics, i.c. his attachment to the German National Socialist Workers Party, were closely connected. He does this by showing how Heidegger attempted to overcome what he regarded as the fundamental errors of philosophy, or metaphysics, by synthesizing philosophy with a distinctive view of Christianity. This led to a rejection of both liberal democracy and socialism and a call for a new form of politics. Heidegger saw 
himself, Rickey argues, as being in a position to "lead the leader," i.e. Hitler.

For many years the debate was over whether Heidegger was really a Nazi at all. Many who acknowledge Heidegger's affiliation with the party either describe this as a personal failing, denying that Heidegger's philosophy has any political dimension at all, or they chalk it up to an occupational hazard of philosophers, namely that they are blind to reality. Rickey argues that there was no absolute separation between Heidegger's philosophy and his concrete polities. Heidegger joined the party, he left it, and he kept faith with it after leaving. That was because the spiritual National Socialism Heidegger advocated provided the political ideal "that is both the source of [Heidegger's] initial positive commitment to Hitler's revolution and also the origin of his later disenchantment with Nazism's failure to live up to his high ideals." Later in his introduction, Rickey describes the connection between Heidegger's philosophy and his politics: "I want to demonstrate that Heidegger's radical critique of the Western, and in particular the modern, metaphysical tradition leads him to advocate a spiritual National Socialism; the authentic understanding of being he contrasts to that understanding characteristic of the Western tradition correlates with his vision of an authentic, postmodern human existence that will deliver humanity from the alienation and desolation characteristic of modernity."

Heidegger, thus, called for the leadership principle as the means of deliverance from modern technological society. Rickey shows how Heidegger made use of Plato's Republic in determining his political resolve. He concludes that Heidegger lost sight of the limits of politics; in his ambition to "lead the leader," Hcidegger forgot about the importance of moderation for politics.

\section{Leonard D. White Award (\$500)}

For the best doctoral dissertation completed and accepted in 1997 or 1998 in the field of public administration.

Award Committee: Mary E. Guy, Florida State University, chair; Laurence O'Toole, University of Georgia; and B. Dan Wood, Texas A\&M University. Recipient: Mark Cassell, Kent State University

Dissertation: "Public Agencies in a Private World: A Comparison of the Fedcral Republic of Germany's Treuhandanstalt and the United States'

Resolution Trust Corporation"

Disserlation Chair: Don Kettl, University of Wisconsin, Madison

Citation: The selection committee evaluated each of the submissions ac- cording to the following set of criteria: (a) innovation/creativity in approaching a research problem with fresh insights that shed new light on the theory and practice of public administration; (b) relevance to practice; (c) theoretical elegance such that the research is on the cutting edge of theory, is argued persuasively and succinctly, and simplifies rather than complicates our understanding; (d) methodological rigor that takes advantage of quantitative and qualitative tools to advance the science of public administration; and (e) clarity/excellence of writing and presentation.

Having set these as the criteria, the committee's selection was a difficult one as each submission exhibited a unique set of strengths. Nevertheless, Mark Cassell's work, "Public Agencies in a Private World: A Comparison of the Federal Republic of Germany's Treuhandanstalt and the United States' Resolution Trust Corporation," emerged as the clear winner.

Cassell's work is a cutting edge analysis that advances theory and develops new empirical approaches to the fundamental question about the role that public agencies play in an interconnected world. Using a comparative approach, this work targets issues of administrative theory and personnel policy to examine how they combine to affect policy outcomes in two different political settings. The study demonstrates the utility of comparative studies of privatization, embedding organizational change within political culture.

In the late 1980 s and early 1990 s, two very different institutions encountered similar problems. Both Germany and the United States created new agencies to acquire and sell nationalized assets. In Germany, these were formerly stateowned assets from East Germany; in the United States, these were assets from failed savings and loans corporations that had been taken over during the bailout.

In a richly detailed and theoretically innovative dissertation, Cassell explains the important role of administrative structures and processes. Conventional wisdom predicts that government agencies, once created, last forever, and that public agencies are unlikely to be capable of adapting quickly to the sophisticated and rapidly changing asset markets. In both of these cases, however, the government agencies did their jobs faster than anyone expected and then went out of business. Drawing on an international comparison, this work discovers which features are nation-based and which are rooted more deeply in the behavior of complex organizations.

Cassell examines three administrative factors: pcrsonnel policies, organizational culture, and organizational struc- ture. In both countries, the administrative elements eschewed a traditional hierarchical model of public organization in favor of a market approach. The outcomes studied include not just the pace of privatization but oversight and accountability as well as legislative mandates such as the prescrvation of employment and industry in Germany and the development of affordable housing and opportunities for minority and women-owned businesses in the United States. A central finding of the study is that administrative factors contributed to an emphasis in both cases on rapid privatization at the cxpense of other legislative mandates.

The comparison of the German case with the U.S. case affords an assessment of how bureaucratic factors shared by both agencies played out differently as they interacted with a larger national policy-making system. While economic models are important, the experience of these two agencies broadens our understanding of privatization as a highly political outcome. The insights from studies such as this are precisely what is needed in the field of public administration as the globe shrinks and policy issues are intertwined politically, gcographically, and conomically.

\section{Franklin L. Burdette/Pi Sigma Alpha Award (\$500)}

For the best paper presented at the 1998 Annual Meeting.

Award Committee: John Fercjohn, Stanford University, chair; Seymour Martin Lipset, George Mason University; and Joan Tronto, Hunter College, CUNY.

Recipient: Charles Stewart III, Massachusetts Institute of Technology

Paper: "Architect or Tactician? Henry Clay and the Institutional Development of the U.S. House of Representatives"

Citation: The paper is an innovative application of sophisticated social science methods and theory to a very important historical problem-explaining the origins of the institutional structure of the House of Representatives and the role Henry Clay played in these developments. Of particular interest is the attempt to trace the relationship between practical tactical actions and the evolution of institutions. Given the sparseness and uneveness of information about this period, there is a particularly great value in leveraging that information with theoretical and statistical techniques in the service of writing better history. Historians and organizational sociologists have as much to learn from this paper as legislative scholars. We commend Stewart for his contribution to analytic history. 


\section{Heinz Eulau Award (\$500)}

For the best article published in the American Political Science Review during 1998.

Aurard Committes: Terence Ball, Arizona State University, chair; Carol Mershon, University of Virginia; and Katherine Tate, University of California, Irvine.

Recipient: John Mark Hansen, University of (hicalgo

Paper: "Individuals, Institutions, and

Public Preferences over Public Finance"

Citation: In "Individuals, Institutions, and Public Preferences over Public Finance" John Mark Hansen raises anew an old question: Is the American mass public sufficiently informed to govern themselves, especially as regards the complexities of public budgeting? Are American budget deficits due to the incoherent and competing demands made upon representatives? Or are they evidence that the constitutional system of checks and balances performs badly when it comes to balancing the budget? Hansen answers that neither is the case. Rather, ours is a system that favors the status quo, and the leadership that would be required to win support for a new and more rational budgeting system is almost wholly absent. Hansen connects his findings to carlicr research into public opinion and succeeds in showing that institutions not only represent public opinion but help to drive it. He thereby helps us to see more clearly the complex character of our institutions and of our citizens' thought-processes.

\section{Ralph Bunche Award (\$500)}

For the best scholarly work in political science, published in 1998, which explores the phenomenon of ethnic and cultural pluralism.

Award Committee: Charles Henry, University of California, Berkeley, chair; Valerie Martinez-Ebers, Texas Christian University; and Richard Shingles, Virginia Tech.

Recipient: Anthony W. Marx, Columbia University

Book: Making Race and Nation: A Comparison of the United States, South Africa, and Brazil (Cambridge University Press)

Recipien: Matthew F. Jacobson, Yale University

Book: Whiteness of a Different Color: European Immigrants and the Alchemy of Race (Harvard University Press)

Citation: In 1931, Ralph Bunche stated: "I am fully persuaded that the Negro of all scholars must first develop a broad international background if his contribution to the solution of our own domestic problems are to make much impress."
A year earlier he had switched from his first dissertation topic "The League of Nations and the Suppression of Slavery" to a proposal to study the mixed races in Brazil. He would contrast racial assimilation there with continued segregation in the United States. However, a ycar later-belicving the Rosenwald Fund would not approve a grant to study the Negro in Brazil--Bunche again shifted his focus, this time to Africa. Although his prize-winning Harvard dissertation was a comparative study of the protectorate and mandate systems in Dahomey and French Togoland, he also did pionecring research in South Africa.

Given his interests, we can safcly assume that Bunche would have been delighted that Anthony Marx has now brought together all three areas in his pioneering work, Making Race and Nation: A Comparison of the United States, South Africa, and Brazil. As comparative history alone, the book would stand as an ambitious contribution to the literature. Marx, however, uses that comparative history to generate original contributions to political theory and the social construction of race.

Marx argues that the political production of race and the political production of nationhood were linked. Where and when states enacted formal rules of domination according to racial distinctions, racism was reinforced, whites were unified as whites, challenges from those subordinated eventually emerged, and major racial conflict ensued, says Marx. However, where racial domination was not encoded by the state, issues and conflicts over race were diluted. Marshalling an impressive range of primary and secondary sources, Marx compares the experience of the United States, South Africa, and Brazil.

His arguments are directly relevant to current political issues in all three countries. Like the work of previous Bunche award winner, Rogers M. Smith, Marx contends that selective exclusion was not tangential to nation-state building, as liberals argue, but was instead central to how social order was maintained. The promoters of democracy building programs in Africa in general and South Africa in particular would do well to heed Marx's advice that democracy nei ther is necessarily inclusive nor ensures that the interests of all will be met. Hc also argues that "color-blindness" in Brazil has been devastating for AfroBrazilians and that similar calls for color-blindness in the United States could prove equally devastating for African Amcricans.

Professor Marx believes the most obvious extension of his argument about race is to the issue of ethnicity more generally. This is precisely the focus of Matthew Frye Jacobson in Whiteness of a Different Color: European Immigrants and the Alchemy of Race. Jacobson traces the fluidity of racial categories from an immense body of research in literature, popular culture, politics, society, ethnology, anthropology, cartoons, and legal history. An engaging writer, Jacobson makes an original contribution to the emerging field of "whiteness studies" by periodizing the stages of racial formation in the United States. Yet, in providing a counter-history of how nationality groups such as the Irish or Greeks became Americans or racial groups like Celts and Mediterrancans became Caucasian, Jacobson does not disavow any participation in twentiethcentury white privilege on the spurious basis of their parents' and grandparents racial oppression. In fact, he states that "it is not just that various white immigrant groups" economic successes came at the expense of nonwhites, but that they owe their now stabilized and broadly recognized whiteness itself in part to these nonwhite groups."

In his 1936 book $A$ World View of Race, Bunche stated that:

Our concept of race is a comparatively recent one. The term race is one employed, however, with a looseness and inaccuracy matehed only by its frequency in our literature. Even the social scientists, the sociologists and anthropologists, have great difficulty in explaining what is meant by "race," and often disagree in their conclusions. The average man in the street, however, will demonstrate an ability to expound at length on the term at the slightest provocation. That is because race is so intimately related to the social and national doctrines with which the layman is familiar, superficially, and to which he gives unreasoning loyalty.

Now, thanks to the efforts of Anthony Marx and Matthew Frye Jacobson, both social scientists and laypersons will have a greater understanding of race and its uses. The 1999 Bunche Prize Committe is delighted to award the Bunche prize for the best scholarly work in political science that explores the phenomenon of ethnic and cultural pluralism to Anthony Marx for Making Race and Nation and to Matthew Frye Jacobson for Whiteness of a Different Color.

\section{Gladys M. Kammerer Award (\$1000)}

For the best political science publication in 1998 in the ficld of U.S. national policy.

Award Committee: Helen Ingram, University of California, Irvine, chair; Mat- 
thew Dickinson, Harvard University; and Dean Yarwood, University of Missouri.

Recipient: Suzanne Mettler, Syracusc University

Book: Dividing Citizens: Gender and Federalism in New Deal Public Policy (Cornell University Press)

Citation: Many contemporary political scientists are searching for the causes of the decline in trust and public spirit among citizens, and have identified such contributors as the media, generational experiences, the decline of parties, and other attributes of the political process. Yet, surprisingly few scholars have thought to examine the impacts of public policies themselves on how citizens view government and define their roles. Suzanne Mettler's Dividing Citizens: Gender and Federalism in New Deal Public Policy looks at citizenship through the lens of the innovative social policies crafted during the New Deal.

This skillfully written book not only informs us deeply about the politics and personalities of this critical time in American political history, but also tackles significant questions about how policy design and administration have the capacity to delimit notions of citizenship, cntitlement, and social contribution. The book builds upon and makes important contributions to scholarship in a number of fields including theories of citizenship, new institutionalism, public policy design, and feminist theory. At the same time, it stands on its own as a highly original contribution to our understanding of the normative impacts of policy tools and patterns of implementation in the American federalist system.

Suzanne Mettler employs a rich historical account to show how pillars of the modern welfare state first erected during the Roosevelt administration (e.g., social policy for the elderly, unemployment insurance, and aid to dependent children) unintentionally defined membership in the polity differently. The book convincingly argues that these public policies gave some Americans, namely working and retired men, national citizenship characterized by entitlement and uniform standards. In contrast, they left others, namely women and minorities (who tended to be parttime wage earners) and agricultural workers, as state citizens subject to local cultures, procedural vagaries, and arbitrary standards of aid disbursement. To prove this, Suzanne Mettler presents a varied and creative array of primary sources: congressional hearings, committee records, letters and memoranda composed by key officials, disbursement data drawn from annual reports of the Social Security Board and records of women's trade and labor unions. In her vivid prose, Suzanne Mettler makes history come alive with real people strug- gling over the design of national policy within the structure of federalism.

As interesting as the stories Suzanne Mettler tells in her book are, the real significance and lasting contribution of the book go far beyond her social welfare case studies. The book richly deserves the Kammerer prize for what it shows are the long-term indirect impacts of policy choices apart from the establishment of policy goals. The designs of public policies embody critical choices about the strength and inclusiveness of American democracy. The New Deal legacy of dividing citizens has had unanticipated and undeniably negative consequences for social citizenship. As the United States moves into an era of decentralizing government, Mettler's central message is critical to remember. The standards of social citizenship must be broad, inclusive, and national in scope if they are to endow citizens with the dignity befitting those with political membership.

\section{Victoria Schuck Award (\$500)}

For the best book published in 1998 on women and politics.

Award Committee: Marjorie Lewis, University of Colorado, Denver, chair; Nancy Burns, University of Michigan; and Clyde Wilcox, Georgetown University.

Recipient: Mary Fainsod Katzenstein, Cornell University

Book: Faithful and Fearless: Moving Feminist Protest Inside the Church and Military (Princeton University Press)

Citation: This provocative and encouraging work moves the ever-constant challenge to oppression of women from very tangible external factors to the more institutionalized intra-organizational facets, particularly the military and Catholic Church in the United States. Her choice of said institutions reminds us of the very traditional tones of each. She contrasts feminist approaches to activism to those of the two institutions, well demonstrating resistance techniques useful in the legal and spiritual battlefields.

As well, her book provides shared insights into "unobtrusive mobilization and civic associationalism." These factors, Katzenstein discusses, are essential partners to successful internal penetration into the barriers of oppression and inequity within the church and military.

Her association between church and (military) state moves us further into such analysis of both institutions as rubrics of our country. Their traditions are long lasting, entrenched within, and empowered by our American society as bastions of defense and hope, protection, and inspiration, the letter and the spirit of the law.

Strategies revealed in breaking barriers of sexual oppression within these two institutions dictate how essential it is to recognize the context in which our active struggles against oppression must occur. Strategies vary as a function of the strength and traditions of our institutions.

This commentary is rich with cases, interviews, and surveys providing implications that move us into the next millennium with renewed hope inspired by the women who shared in the development of this work. Katzenstein provides the smooth stones necded to slay the "Goliath" facing women in their quest for equity of opportunity within two of the most powerful institutions in this universe.

Katzenstein also dialogues with works of authors in many disciplines, philosophy, religion, multicultural ethics, politics, social servants, public administrators, and so many more. She challenges issues of the secular and sacred, demonstrating that oppression knows no bounds.

Let us pay a tribute to a work that inspires in us an unconditional activism against oppression wherever it is found.

\section{Woodrow Wilson Foundation Award $(\$ 5,000)$}

For the best book published in the United States during 1998 on government, politics, or international affairs.

Award Committee: Hanes Walton Jr., University of Michigan, chair; Barbara Sinclair, University of California, Los Angeles; and Randolph Siverson, University of California, Davis.

Recipient: Rodney Hero, University of Colorado

Book: Faces of Inequality: Social Diversity in American Politics (Oxford University Press)

Citation: In Faces of Inequality, Rodney Hero argues that a state's social diversity is the single most important determinant of its politics and policies. Conceptualizing social diversity in two dimensions-racial and ethnic-Hero offers cogent arguments for the primacy of social diversity as a shaper of political processes and policy outcomes and provides considerable empirical support for his thesis. The theoretical and empirical importance of the subject addressed, the insightfulness of its arguments, the range of its empirical tests and the potential fruitfulness of his thesis for future rescarch make Faces of Inequality deserving of the Woodrow Wilson prize. 


\section{Benjamin E. Lippincott Award (\$1500)}

For a work of exceptional quality by a living political theorist that is still considered significant after a time span of at least 1.5 years since the original publication datc.

Award Committee: Michael Zuckert, University of Notre Dame, chair; Leslie Palul Thicle, University of Florida; and Bomnic Honig, Northwestern University.

Recipient: William E. Connolly, Johns Hopkins University

Book: The Terms of Political Discourse (Heath Publishers)

Citation: William E. Connolly's The Terms of Political Discourse has been shaping the intellectual perspectives and research orientations of students of politics and political theory for two-and-ahalf decades. Accessible to upper-level undergraduates, yet challenging to advanced scholars, Terms of Political Discourse asserts that the language of politics is not a neutral medium. It is an institutionally structured set of meanings that channel political thought and action. Torms of Political Discourse explores the politics of political discourse itself. It analyzes the concepts and ideas that are the coin of the realm of political theory and investigates the epistemological and normative commitments that are embedded in these terms and inherent to their analysis. Originally published in 1974 and now in its third edition, Connolly's work revitalized W. B. Gallic's notion of "essentially contested concepts" (1956) while anticipating "postmodern" concerns with the sociolinguistic construction of identity and the endemic ambiguities these constructions negotiate or obfuscate.

\section{John Gaus Award $(\$ 1,500)$}

The John Gaus Distinguished Lecturer Award Honors the recipient's lifetime of exemplary scholarship in the joint traditions of political science and public administration and, more generally, recognizes and encourages scholarship in public administration.

Award Committee: Robert F. Durant, Texas A\&M University, chair; Lenneal Henderson, University of Baltimore; Dvora Yanow, California State University, Hayward.

Recipient: H. Gcorge Frederickson, University of Kansas

Citation: The recipient of the 1999 John Gaus Award is H. George Fredcrickson, Edwin O. Stene Distinguished Professor of Public Administration at the University of Kansas. The Gaus Award Committec unanimously selected Professor Frederickson for this award becausc of his distinguished contributions to theory, research, and practice in the joint traditions of public administration and political science. Most notable in this regard are his pathbreaking scholarship regarding a theory of social cquity, his research on the place of citizenship and ethics in public administration, and his painstaking and untiring efforts to nurture and institutionalize the advancement of public administration. Professor Frederickson has bequeathed a substantial, important, and profound intellectual legacy to scholars, scholarship, and civic society in the United States and abroad. Dwight Waldo once wrote of John Gaus that his contributions to the field did not redraw the basic map, but they have changed it significantly. No less, and arguably more, can be said of Professor Frederickson's career.

In Frederick Mosher's edited retrospective, American Public Administration: Past, Present, and Future, various contributors refer to John Gaus as a disciplinary leader who, with others, "made explicit the inadequacies of the then current approaches to research and training," "had enormous influence" on younger scholars, and "enlarged and enriched the heritage." Perhaps no better summary exists of Professor Frederickson's carcer. Beginning in the late $1960 \mathrm{~s}$, he developed a theory of social equity that he continues to elaborate and extend and that represented at the time a turning point in public administration theory. Like others before him, he wrote that bureaucratic values were critically important because public managers took actions loaded with value choices, actions that entailed more than merc efficiency and economy. Unlike others, however, he averred that social equity not only had to be added to this pantheon of administrative values, but it had to be given preference among them. For administrators, Frederickson's "new public administration" meant that a burning desire to advance social equity had to replace neutrality as the primary critcrion upon which they acted and were evaluated. While the academy debated how "new" Frederickson's public administration movement was, the substance of his clarion call to action could not--and has not to this day-been ignored in the field. Today, the equitable treatment of citizens is a concern that administrators ignore at their own and their agency's peril. George Frederickson's work played no small part in making it so.

Similarly, his writings on social equity and his leadership of the new public administration are both unparalleled and legendary within the academy. Not only is his original essay on social equity still being reprinted in Classics of Public Administration, but the book, New Public Administration, in which he first outlined his thcory of social equity, was selected by Choice as one of the outstanding academic books of 1981-82. Nor has the impact of his writings been limited to the United States. New Public Administration has been translated into German, Japancse, Korean, and Indonesian. Since then, his work on applications of social equity has appeared in "The Lineage of New Public Administration" in Administration and Society (1976), "Public Administration and Social Equity" in Public Administration Review (1990), and "Comparing the Reinventing Government Movement with the New Public Administration" in Public Administration Review (1996).

His most recent book, The Spirit of Public Administration (1997), places social equity in the context of political values and public ethics in ways that would have made John Gaus proud. Put most succinctly by James Perry, Frederickson's theory of social equity has become the standard answer to questions of fairness and justice in public administration. Moreover, like Gaus' clarion call in The Frontiers of Public Administration, Frederickson's persistent challenge to the field has been one of finding "some new source of content, of opportunity for the individual to assert some influence on the [changing] situation in which he finds himself" (Gaus 1936).

Professor Frederickson's scholarship has also shared Gaus' fascination and concern in Reflections on Public Administration with the interplay of individuals, ecology, and public administration. Especially noteworthy in this regard have been Professor Frederickson's practical and theoretical contributions to understanding the relationship between societal change, citizens, and their relationship to government. This intellectual project began with the publication of Neighborhood Control in the 1970)s and the symposium, "Citizens, Politics and Administration in Urban Neighborhoods" in Public Administration Review (1972). In each, his central argument was that public administration necded a theory that elevates the role (Frederickson calls it the "office") of citizen and the importance of citizenship. Developing this theory has driven his work ever since, most prominently in the publication of such classics as "The Recovery of Civism in Public Administration" (Public Administration Review, 1982) and his coediting of a special issue of the Public Administration Review on "Citizenship and the Public Service" (1984). Thus, as Perry again puts it so well, "long before the current popularity of the civil society movement, Frederickson had the foresight to build bridges between effective bureaucratic functioning and citizenship."

As the primary exponent of the importance to practitioners and scholars of 
understanding the "ecology" of public administration, John Gaus was well aware of the impacl of citizens' perceptions about the honesty of government on their political actions. Professor Frederickson's scholarship has shown a similar concern, one that began in earnest in the mid-1980s. His "The Public Service and the Patriotism of Benevolence," coauthored with David K. Hart and appearing in Public Administration Review (1985), is a classic in the study of public administration ethics. His article, "Can Public Officials Correctly Be Said to Have Obligations to Future Generations?" (Public Administration Review 1994), represents a seminal treatment of the impact of intergenerational ethics on the decisions of public administrators. This was followed by an article coauthored with his son, David G. Frederickson, titled "Public Perceptions of Ethics in Government: The Paradox of Distance and the Problem of Role Differentiation," which appeared in The Annals of the American Academy of Political and Social Sciences (1995). During this time, he also organized a conference on theoretical and research perspectives on ethics in public administration that resulted in a book chapter titled "Research and Knowledge in Administrative Ethics" (Handbook of Administrative Ethics 1993), and a volume of original cssays he edited under the title Ethics and Public Administration (1993). His most recent treatment of this topic is a study titled "Ethics and the New Managerialism," which will appear in an upcoming issuc of Public Integrity. As Richard Stillman suggests, Gaus' clarion call was to use ethics and other elements of administrative "ecology" for diagnosis. Frederickson has done his utmost to see that public managers have the tools for doing just that.

Yet, only citing Frederickson's research contributions is to understate his impact on the field. No one has done more to encourage scholarship and research in public administration over the past two decades than George Frederickson, nor to nurture and mentor younger professionals in the field. Begin ning with his intellectual leadership in the original Minnowbrook Conference in 1968 , he has organized many conferences and symposia where scholars can present their work. Concerned in the late 1980s about the quality of research and the development of coherent theory in public administration, he cofounded and edited the Journal of Public Administration Research and Theory (J-PART). As the tenth anniversary of $J-P A R T$ draws near, it is already recognized as among the top journals in the field and as a premier outlet for advanced empirical research and theoretical development.

In sum, for over 30 years Professor
Frederickson has been a splendid example of the best that public administration scholarship has to offer to those facing the choices, challenges, and opportunities that John Gaus saw so vividly in his day. In many ways, Frederickson's most recent book, The Spirit of Public Administration, is the best illustration of how he has masterfully blended the traditions of public administration and political science to nurture scholarship, practice, and our ethical and normative bearings in today's era of turbulence and change. As Laurence E. Lynn Jr. wrote of this book, "George Frederickson's principled discourse on the study and practice of public administration reflects the wisdom of broad experience and an overarching intellect. This book is an indispensable antidote to contemporary pleas that we narrow our sense of what governance is all about." Understanding the rise of the administrative state in America is unimaginable if one does not understand Gaus' thesis in American Society and Public Administration: Faced with fundamental change, government agencies would "help craft new institutional bases ... [to] . . . enable the individual to find development ... satisfaction .... and some scnse of purpose." Unimaginable, as well, is understanding the prospects and perils of our administrative future without George Frederickson's scholarship, sense of professionalism, and commitment to excellence over the past three decades.

\section{Carey McWilliams Award (\$500)}

Presented each year to honor a major journalistic contribution to our understanding of politics.

Award Committee: Earl Black, Rice University, chair; Paul Herrnson, University of Maryland; and Martha Joynt Kumar, Towson State University. Recipient: Dan Balz, The Washington Post

Citation: For many years, Dan Balz has been one of America's most consistently insightful political reporters. His ability to sense trends and developments in American politics and report them with precision and thoughtfulness make him an ideal winner of the Carey McWilliams Award.

Balz first came to national attention for the quality of his reporting as a Washington Post correspondent stationed in Texas. The experience he gained in covering politics in Texas and nearby states gave him the sophisticated understanding of grassroots politics that continued to inform his work when he later moved to Washington. As one of the Post's national correspondents, his stories on American campaigns and party politics have been models of balanced and creative journalism.

In addition to his daily reporting for the Post, Balz has made a major contri- bution to our understanding of politics through his 1996 book Storming the Gates: Protest Politics and the Republican Revival, a revelatory analysis of American politics in the mid-1990)s. Written with another premier reporter, Ronald Brownstein of The Los Angeles Times, Storming the Gates is an illuminating account of the circumstances surrounding the Republicans' unexpected congressional victories in 1994. It represents the sort of lucid, dispassionate reporting that cnables political scientists to better understand the issues, events, and personalities that shape American politics.

We are pleased to recognize his many contributions with the 1999 Carcy McWilliams Award.

\section{Charles E. Merriam Award (\$500)}

Given biennially to a person whose published work and career represents a significant contribution to the art of government through the application of social science rescarch.

Award Committee: Thomas E. Mann, Brookings Institution, chair; Samuel L. Popkin, University of California, San Diego; and Francine R. Rabinovitz, Hamilton, Rabinovitz \& Alschuler, Inc.

Recipient: Allen Schick, University of Maryland

Citation: The Charles E. Merriam Award is now given biennially to a person whose published work and carcer represents a significant contribution to the art of government through the application of social science research. Allen Schick, whose scholarship on budgeting and public management has shaped the practice of government around the globe, is richly deserving of this award.

Judged by conventional standards, Schick has been a creative and prolific scholar for 35 years. His more than a dozen books include Budget Innovation in the States, Congress and Money, The Capacity to Budget, and The Federal Budget: Politics, Policy, Process. He holds records for the most articles published in Public Administration Review (1.3) and for the most times recognized for the best article published in that journal (4). He has won significant book (Brownlow and Hardeman) and career (Waldo and Wildavsky) awards as well as a Guggenheim Fellowship.

Schick's scholarly work has ranged across substantive domains and geographical areas. He has studied budgeting institutions and practices, executive and legislative, at the state and national level in the United States and in industrialized democracies and developing countries around the world. He has done highly original work on the historical development of lawmaking and legislative form in the United States, including health care entitlements and the recent development of omnibus legislation. He has analyzed the politics of bu- 
reaucratic reform in the U.S. and the spread of new models of public management throughout the industrialized world.

But Schick's social science-based contributions to the art of government go well beyond this impressive scholarly record. In addition to his academic appointments at Tufts and since 1981 the University of Maryland, he spent a decade as a senior specialist at the Congressional Research Service and has been affiliated with three Washington think tanks. Schick has also directed major studies of expenditure control and public management for the OECD and the World Bank and was commissioned by the Crown to evaluate New Zcaland's innovative and far-reaching government reforms. These latter activities, and the publications that flowed from them, have made him a legendary figure in the worlds of public management scholarship and practice around the globe.

There is more. Schick played a critical role in helping Congress write the Budget and Impoundment Control Act of 1974. He has counseled numerous members of Congress and their staffs on issues of budgetary control. He has advised ministers and senior civil servants in scores of countries. He is a brilliant lecturer who has educated and entertained thousinds of grateful participants in his public and academic seminars.

We have no doubt that Charles Merriam would be honored and pleased to have the award named in his memory conferred on Allen Schick.

\section{The Hubert H. Humphrey Award (\$500)}

Presented each year in recognition of notable public service by a political scientist.

Award Committee: John Odell, University of Southern California, chair; Walter Broadnax, University of Maryland; and Marjoric Hershey, Indiana University.

Recipient: Marjorie Mowlam, Secretary of State for Northern Ireland, Britain

Citation: The Humphrey Award is given annually for notable public service by a political scientist. This year's honoree, Dr. Marjorie (Mo) Mowlam, was educated at Durham University and the University of lowa, where she earned the Ph.D. in political science. She was assistant professor of government at Florida State University from 1977 to 1979. After returning to the United Kingdom, she taught political science at the University of Newcastle and served as lecturer and administrator at the Northern College, Barnsley.

Since 1987 she has been the Labour Member of Parliament for Redcar. She was elected to the Shadow Cabinet for the first time in 1992, when she was given responsibility for women's issues.
After 1994 she was promoted to Shadow Northern Ireland Secretary. In 1995 she was also elected to the Labour Party's ruling National Executive Committee.

After the Labour victory in 1997, Dr. Mowlam was appointed Secretary of State for Northern Ireland. With her great personal warmth, courage, and Herculean efforts, she helped secure the historic 1998 Good Friday agreement. As Senator George Mitchell, chairman of that negotiation, wrote in his book Making Peace, "Mo traveled to Northern Ireland as soon as she was named secretary of state and literally dived into the problem, wading into crowds with joy and energy.... She made an early, strong impact on the process and proved to be invaluable to its eventual success."

Dr. Mowlam has won public acclaim and affection throughout and beyond the United Kingdom for her good humor, political skill, and, especially, her tireless dedication to securing peace. She has received a number of awards, including "Most Effective Member of Parliament" from The House Magazine. So great has been the acclaim, in fact, that this March The Guardian observed, "sainthood cannot be far away."

But first, with admiration and hopes for even more notable public service, the American Political Science Association is delighted to confer the 1999 Hubert H. Humphrey Award on Dr. Marjorie Mowlam.

\section{James Madison Award (\$2,000)}

Presented once every three years to a living American political scientist who has made a distinguished scholarly contribution to political science.

Award Committee: Raymond Wolfinger, University of California, Berkeley, chair; Jennifer Hochschild, Princeton University; and John J. Mearsheimer, University of Chicago.

Recipient: Kenneth N. Waltz, Columbia University

Citation: A common theme connects the thinking of James Madison and Kenneth Waltz, the recipient of the Madison Award. Madison was deeply concerned about how to prevent the concentration of power within the American government. His answer was to build a system of checks and balances into the Constitution. He helped design a government in which its different parts had the power to keep "each other in their proper places." He maintained that "ambition must be made to counteract ambition." Although Waltz is a student of international politics, not American politics, the idea of balancing power with power is probably the central theme in his work.

Waltz is one of the great international relations theorists of the twentieth cen- tury. His arguments have stood at the center of almost every major debate about international relations over the past 50 years: the causes of war, the effects of the nuclear revolution, the effects of economic interdependence, the effects of democracy on formulating foreign policy, and the effects of bipolarity on world affairs.

Waltz's Theory of International Politics (1979) has become a classic since its publication 20 years ago. No serious international relations scholar can ignore it. Waltz has also produced two other seminal works: Man, the State and War (1959) and The Spread of Nuclear Weapons (1981). Both are widely read and deeply influential. Man, the State and War has sold over 100,000 copies, and its distinction between the three "images" or levels of analysis is an IR field staple. Similarly, Waltz's arguments are mentioned in almost all scrious discussion of the likcly consequences of nuclear proliferation. Few scholars can claim to have written a single lasting book; Waltz has written three major statements that have stood the test of time.

Despite Waltz's pervasive influence, his arguments have been rejected by many. He was one of a small and lonely band when he first voiced his very early opposition to American involvement in Vietnam in 1964. His arguments about the effects of nuclcar proliferation have never been popular. His calls during the Cold War for U.S. defense cuts and for U.S. restraint overseas did not win the day. The realism that infuses his work remains a minority view among IR scholars. Liberalism is the American credo; realism is the lesser tendency. Waltz's realist stance has always had him sailing against prevailing liberal winds. Yet, Waltz never shied from challenging conventional wisdoms and from making arguments that few accepted, at least at first.

Accepted or not, Waltz's ideas have had remarkable staying power. His core arguments are taught in most graduate IR theory seminars around the United States, and are well known to today's students of international politics. The staying power of these ideas is enhanced by the elegance of Waltz's theories and the force and clarity of his writing.

Waltz has also had a major influence on the discipline through his teaching and training of graduate students. At Berkeley, where he spent most of his career, he advised an impressive array of Ph.D. students who then became important scholars in their own right. That list includes, among others, Barry Posen (MIT), Stephen Walt (Harvard), Stephen Van Evera (MIT), James Fearon (Stanford), Robert Powell (Berkeley), Shaj Feldman (Jaffe Center, Tel Aviv University), Shibley Telhami (Maryland), and Avery Goldstein (Penn). For those 
and other students, he served as a powerful role model who taught by his words and deeds that real scholars do not waste their time dwelling on the small or tailoring their views to meet current fashions. Instead, Waltz stressed the importance of addressing the most urgent questions, however hard they might be to answer; and the need to bravely argue whatever seemed true, even if this brought only brickbats. Waltz also taught by example that great teachers should leave their students wide room to differ with them, as his students often have. 